\title{
Assessing the long-term effect of exposure to dispersant- treated oil on fish health using hypoxia tolerance and temperature susceptibility as ecologically relevant biomarkers
}

\author{
Mauduit F. ${ }^{1,}{ }^{*}$, Farrell A.P. ${ }^{2}$, Domenici P. ${ }^{3}$, Lacroix C. ${ }^{4}$, Le Floch S. ${ }^{4}$, Lemaire Pierrette ${ }^{5}$, \\ Nicolas-Kopec A. ${ }^{6}$, Whittington M. ${ }^{6}$, Le Bayon Nicolas ${ }^{7}$, Zambonino Jose-Luis ${ }^{7}$, Claireaux Guy ${ }^{1}$
}

${ }^{1}$ Université de Bretagne Occidentale, LEMAR (UMR 6539), Centre Ifremer de Bretagne; 29280

Plouzané ,France

${ }^{2}$ University of British Columbia, Department of Zoology and Faculty of Land and Food Systems, 2357

Main Mall, University of British Columbia; Vancouver BC, V6T 1 Z4,Canada

${ }^{3}$ CNR-IAMC; Località Sa Mardini; 09072 Torregrande Oristano, Italy

${ }^{4}$ CEDRE; Research Department; 715 rue Alain Colas CS 41836, Brest 29218-Cedex 2, France

${ }^{5}$ Total Fluides, 24 Cours Michelet; La Défense 1092069 Paris La Défense-Cedex, France

${ }^{6}$ The International Tanker Owners Pollution Federation Limited (ITOPF); 1 Oliver's Yard, 55 City Road London EC1Y $1 \mathrm{HQ}$, United Kingdom

7 Ifremer, LEMAR (UMR 6539), Centre Ifremer de Bretagne; 29280 Plouzané, France

*Corresponding author : F. Mauduit, email address : florian.mauduit@gmail.com

\begin{abstract}
:
Consequences of exposure to polyaromatic hydrocarbons (PAH), toxic components of crude oil, on fish has been widely documented due to their ecological and economical importance. However, although forming a valuable and consistent body of knowledge, use of these data in spill response is limited. Objective of the present study was thus to facilitate the translation of published data into information of operational value. For this, we investigated the dose-response relationship between dispersant-treated oil exposure and ecologically-relevant consequences by combining laboratory and field experiments. Effects were examined over almost a year using juveniles of the slow growing, commercially important European sea bass (Dicentrarchus labrax). Moreover, a reliable interpretation of biomarkers response requires a complete knowledge of the factors likely to affect their response. Inter-populational variability is of particular importance in environmental impact assessment since biomarkers' response from population collected in an impacted area are classically compared to those collected in a clean site. Our study revealed no effect of the exposure to dispersant-treated oil on fish hypoxia tolerance and temperature susceptibility 1 and 11 months post-exposure. Similarly, no effect of the exposure was observed on fish coping ability with environmental contingencies in the field, regardless of the dose tested. Thus, we are confident in suggesting that a 48-h exposure to chemically treated oil do not affect the ability of sea bass to cope with mild environmental contingencies. Finally, investigation of interpopulation variability revealed large differences in both hypoxia tolerance and temperature susceptibility among the 2 populations tested, suggesting that this variability may blur the interpretation
\end{abstract}


of populations comparisons as classically practiced in impact assessment.

Keywords: oil spills, polycyclic aromatic hydrocarbons (PAHs), fish indices, ecotoxicology, environmental toxicology
Abbreviations
CONT:
Control
CTmax: $\quad$ Critical thermal maximum
CV: $\quad$ Coefficient of variation
HCT: Hypoxia challenge test
ILOS: Incipient lethal oxygen saturation
O25D1: $\quad 25 \mathrm{~g}$ of oil $+1 \mathrm{~g}$ of dispersant
O125D5: $\quad 125 \mathrm{~g}$ of oil $+5 \mathrm{~g}$ of dispersant
O250D10: $\quad 250 \mathrm{~g}$ of oil $+10 \mathrm{~g}$ of dispersant
$\mathrm{PAH}$ : Polycyclic aromatic hydrocarbons
RGR: $\quad$ Relative growth rate
SBSE-GC-MS: stir bar sorptive extraction-thermal desorption-gas chromatography-mass
TCT: $\quad$ Temperature challenge test
TLOE: $\quad$ Time to loss of equilibrium 


\section{Introduction}

While oil reserves remain the world's main source of energy (Birol, 2014), supply and demand are rarely located in the same place. Consequently, large quantities of crude oil are transported by ship between production sites and refineries for consumption. Over the last 40 years, transportation by sea of oil products has doubled, amounting to about 3000 million tons in 2016 and representing about one third of global maritime trade (UNCTAD, 2005; ITOPF, 2016; UNCTAD, 2017). Although increased oil trade mechanically implies increased risk of accidental release, the number of large spills (> 700 tons) actually decreased over the same time period. For instance, the number of large spills observed during the early 2000 s was $<10 \%$ of that seen during the 1970s (ITOPF, 2016). Nevertheless, even though less frequent, large oil spills remain an economic and ecological concern.

Resorting to dispersants has been a response option to oil spills since the landmark SS Torrey Canyon accident in 1967 in the UK. However, although effective in breaking up oil slicks at sea, first generation dispersants were toxic to aquatic life and their application resulted in severe additive environmental impacts (Nelson-Smith, 1968). Since then, however, new formulations have been developed and current dispersants are mixtures containing a high concentration of surfactants in a water-miscible solvent (Lessard and DeMarco, 2000). Despite these improvements, responders are still reluctant to consider recourse to dispersants as an appropriate response. The main reason for this persisting disinclination is the resulting increased bioavailability of oil compounds, particularly polycyclic aromatic hydrocarbons (PAH), and the threat that it represents for marine species (Ramachandran et al., 2004).

This article is protected by copyright. All rights reserved 
To better assess the toxicity of oil spills and the consequences of their chemical treatments, numerous studies have been conducted and impairments of fish development, cardiorespiratory function, swimming performance, hypoxia tolerance, immunity, growth and survival have been documented (Heintz et al., 2000; Claireaux et al., 2004; Davoodi et Claireaux, 2007; Claireaux and Davoodi, 2010; Milinkovitch et al., 2011; Incardona et al., 2014; Esbaugh et al., 2016, Johansen and Esbaugh, 2017; Khursigara et al., 2017). However, although forming a valuable and consistent body of knowledge, this abundant literature remains of limited operational value. Four reasons may explain this limitation: 1) these studies mostly focused on short-term toxicological effects; 2) they are generally based on the measurement of low-organizational level biomarkers; 3) they principally targeted early life stages and/or model species of low socio-economic value; and 4) within- and among-population variability confounds biomarkers responses, making the interpretation of their changes difficult.

The first reason for the difficult translation of published data into operational information relates to the prominence of short-term assessments $(<1$ month) following oil exposure. Full evaluation of impact of an oil release requires that organisms' long-term responses be considered, as these may extend well beyond a few weeks. This has been reported, for instance, in pink salmon Oncorhynchus gorbuscha, which displayed reduced growth and marine survival as long as 2 years after having been exposed to Exxon Valdez-like oil conditions (Heintz et al., 2000). The long-term monitoring of fish response also allows giving consideration to a generally unappreciated component of impact assessment i.e., the capacity to recover ecological performance and health. It has been shown in juvenile orange-spotted grouper (Epinephelus coioides), for example, that the disruption of the intestine mucosal integrity and function observed after a 4-weeks exposure to foodborne benzo[a]pyrene was reversible within a month (Yuen et al., 2007).

This article is protected by copyright. All rights reserved 
The second reason for the poor transposition of scientific knowledge into operational tools relates to the wide use of low organizational-level biomarkers as gauges of impacts. Although helpful to establish that exposure to a contaminant occurred, low-level biomarkers are difficult to reconcile with the need of decision makers for ecologically-relevant, whole animal indicators of performance (Lam and Gray, 2003). Furthermore, the interpretation of these biomarkers requires that consideration be given to the fact that changes may not necessarily indicate a disorder but simply denote an homeostatic response in progress (Calow and Forbes, 1998).

The third reason for current lack of operational information results from the fact that most recently published studies targeted early life stages (Carls et al., 1999, 2008; Incardona et al., 2004, 2005, 2008, 2014; Brette et al., 2014) and/or model species of low socio-economic relevance (Le Bihanic, 2014; Vignet et al., 2014abc; Perrichon et al., 2014; 2016). Physiology and behavior vary markedly among fish species and life stages, and these differences make the transposition of available information practically impossible. For instance, while it is admitted that oil exposure is detrimental during early developmental stages, fish at later life-stages are more resilient to oil, with greater capacity to metabolize and detoxify from PAH as well as with thicker skin which limits the diffusion of contaminant into the tissues (Hawkins et al., 2012).

Last but clearly not least, a major limitation to the extrapolation of experimental results to field situations follows from current poor understanding of within- and among-populations variability in fish performance, and their variation over time. When an accidental release occurs, environmental impact assessment classically consists in comparing the level of a biomarker in an exposed population to that of an unexposed, control population (Stein et al., 1992; Stagg et al., 2000). Such an approach is premised on the double assumption that inter-population variability in the biomarker level is negligible and that when a difference is observed between This article is protected by copyright. All rights reserved 
the exposed and the control populations, it is fully attributable to the presence of a contaminant in one population's environment. Unfortunately, this double assumption is generally false and can be the cause of inappropriate conclusions regarding the impact of a pollutant. For instance, it has been demonstrated that the response of integrated, whole animal biomarkers such as swimming capacity and hypoxia tolerance are influenced by the fatty acid composition of the diet or by environmental conditions during early life stages (McKenzie et al., 1995; Vanderplancke et al., 2015). This clearly suggests that no direct, between-populations comparison can be made in the absence of sufficient information regarding these populations' environmental history and condition.

In a previous study, using the slow growing, commercially important European sea bass (Dicentrarchus labrax), we experimentally addressed some of the above issues (Mauduit et al., 2016). In that experiment, the impact of oil exposure was assessed using whole animal indicators of performance (hypoxia tolerance, temperature susceptibility, swimming performance). Moreover, inter-individual variability and temporal stability of these markers was examined during a period which extended until one year post exposure. The main results of this experiment were that hypoxia tolerance, temperature susceptibility and swimming performance are temporally stable and ecologically relevant indicators of individuals' performance. We also demonstrated that these indicators were altered up to 1 month postexposure to a mixture of oil and dispersants. However, these effects were only transient as control and exposed fish displayed similar growth and survival following their transfer to seminatural field conditions (from 2 to 6 months post-exposure). Moreover, fully recovered hypoxia tolerance, temperature susceptibility and swimming performance were measured 11 months post-exposure.

This article is protected by copyright. All rights reserved 
To follow up to our earlier study, the present work aimed at addressing three additional points which relate to the dose-effect relationship, to the pattern of natural selection in the field and to inter-population variability. Our previous experiment indeed demonstrated that extending postexposure functional assessment beyond a few weeks revealed fish recovery capacity. However, this observation was made after exposure to a relatively low dose of chemically-treated oil and the limit to fish recovery capacity remained to be evaluated. Our previous work also included a long term impact assessment using semi-natural field mesocosmes. In that experiment survival rate was in excess of $60 \%$. However, using the same semi-natural field mesocosmes, and similar oil exposure conditions, Claireaux et al. (2013) reported a survival rate of approximately $30 \%$. This discrepancy suggests the possibility that high inter-annual variation in the conditions governing natural selection may interfere in revealing post-exposure functional impairments and their downstream ecological consequences. Finally, although our previous study investigated inter-individual variability in biomarkers' responses, and demonstrated the need to test large numbers of fish, the confounding influence of populational variability remained to be examined to verify the reliability of population-level comparison as classically practiced in impact assessment procedure.

To address these issues, the present investigation combined laboratory- and field-based experiments to assess the long-term ecological consequences of an exposure to incremental doses of dispersant-treated oil. The experimental population was first screened for hypoxia tolerance and temperature susceptibility and fish performances were then compared to those reported by Mauduit et al., (2016). Fish were then exposed to incremental doses of dispersanttreated oil for 48 hours before being allowed to recover for a 1-month period. At that time, fish hypoxia tolerance and temperature susceptibility were measured for a second time to assess the effects of the exposure. Experimental populations were then transferred for a 4-month period This article is protected by copyright. All rights reserved 
into semi-natural mesocosmes to assess the long-term ecological consequences of oil exposure. At the end of the field period, fish that had survived were brought back into the laboratory and their hypoxia tolerance and temperature susceptibility determined for the third time to attest recovery.

\section{Materials and methods}

\subsection{Animals}

One-year-old sea bass (Dicentrarchus labrax; $\mathrm{n}=406 ; 12.87 \pm 0.04 \mathrm{~cm}$ in total length; $26.7 \pm$ $0.4 \mathrm{~g}$ in body mass) were transported from a local fish farm (Aquastream, Lorient, France) to the laboratory (Ifremer, Brest, France) where they were placed in 400-L, indoor tanks and acclimated for two months to laboratory conditions under natural photoperiod and temperature (salinity 30-32 \%o). They were fed daily ad libitum with a commercial diet (Neo Start Coul 2, Le Gouessant). Two weeks before the experiment started, fish were anaesthetized (MS-222; $100 \mathrm{mg} / \mathrm{L}$ ) and implanted subcutaneously with an identification tag (RFID; Biolog-id, France). This allowed mixing fish from the different treatments in the same tank, avoiding a potential tank effect. Feeding was discontinued $24 \mathrm{~h}$ before any manipulation or experiment. All protocols were in conformity with current rules and regulations in France.

\subsection{Experimental protocol}

The experimental schedule is summarized in Fig. 1. The timeline was established to meet our goal of testing long-term effects. Briefly, individually tagged fish were submitted to suite of challenge tests conducted 1 month before (March), 1 month after (May) and again 11 months after (March) a 48-h exposure to one of four experimental treatments (Control, $25 \mathrm{~g}$ of oil +1 This article is protected by copyright. All rights reserved 
$\mathrm{g}$ of dispersant, $125 \mathrm{~g}$ of oil $+5 \mathrm{~g}$ of dispersant, $250 \mathrm{~g}$ of oil $+10 \mathrm{~g}$ of dispersant). During the period June to November (from 2 to 7 months post-exposure) fish were held in a field mesocosm to assess the effect of experimental treatments upon their capacity to thrive under semi-natural conditions. After this period in the field, survivors were brought back into the laboratory. During the entire laboratory experimental period, fish were submitted to the natural daily and seasonal cycles for temperature (between 11 and $20^{\circ} \mathrm{C}$ ), photoperiod and salinity (30-32 PSU).

\subsection{Fish transport}

The experiment mobilized the resources of three experimental sites and it was necessary to transport fish among them. Fish were primarily reared at Ifremer facilities, while experimental oil exposure was conducted at Centre of Documentation, Research and Experimentation on Accidental Water Pollution (Cedre), about $12 \mathrm{~km}$ from Ifremer laboratory. The mesocosm experiment took place $450 \mathrm{~km}$ from Brest. Before transfer into the transport tank $\left(1 \mathrm{~m}^{3}\right)$, fish were anaesthetized (MS-222; $100 \mathrm{mg} / \mathrm{L})$ and a maintenance dose of anesthetic (MS-222; 25 $\mathrm{mg} / \mathrm{L}$ ) was maintained during travels. Water temperature and oxygen levels were monitored continuously and maintained at seasonal values.

\subsection{Experimental exposure}

In April 2014, fish $(\mathrm{n}=406)$ were transported to the Cedre and placed in $2 \mathrm{~m}^{3}$ tanks supplied with open flow seawater $\left(\mathrm{T}^{\circ} \mathrm{C}=12^{\circ} \mathrm{C}\right)$. Fish were allocated to the various exposure tanks in such a way as to ensure similar frequency distribution of time to loss of equilibrium (TLOE) at the hypoxia and temperature challenge tests conducted 1 month pre-exposure (Log-rank, $\mathrm{p}=$ 0.184 and 0.881 , respectively). Temperature, salinity and photoperiod followed seasonal variations and fish were not fed the day before and throughout the oil exposure period. A set of This article is protected by copyright. All rights reserved 
12 polyethylene tanks (300 L) equipped with homemade mixing devices comprising a funnel and a submersible bilge pump was used to expose the fish (Milinkovitch et al., 2011).

Four experimental treatments were tested in triplicate, i.e., control (labelled CONT), $25 \mathrm{~g}$ of oil plus $1 \mathrm{~g}$ of dispersant (O25D1), $125 \mathrm{~g}$ of oil added with $5 \mathrm{~g}$ of dispersant (O125D5) and $250 \mathrm{~g}$ of oil added with $10 \mathrm{~g}$ of dispersant (O250D10). The petroleum used in the study was a Crude Arabian Light (CAL). This oil is composed of 54\% saturated hydrocarbons, $10 \%$ polar compounds and 36\% aromatic hydrocarbons. The dispersant (Finasol OSR 52, Total Fluides) was used in accordance with manufacturer's recommendation (Dispersant/oil ratio of 4\%). Oil and dispersant were mixed in a bottle by shaking and the mixture was directly poured in the tanks which were then vigorously bubbled with air overnight to mimic a $12 \mathrm{~h}$ aging of an oil slick at sea (Nordvik, 1995).

Fish were exposed to these treatments for a 48-h period in order to mimics the conditions that they are liable to face off during an oil spill (Milinkovitch et al., 2011; Claireaux et al., 2013; Esbaugh et al., 2016; Mauduit et al., 2016). Following the exposure period, fish were recovered, briefly bathed in clean seawater to avoid cross-contamination and put back in their rearing tank for one week before being returned to the Ifremer laboratory. No mortality was observed during and for one month after the exposure.

\subsection{Challenge tests}

The two challenge tests (hypoxia and temperature) have been fully described (Mauduit et al., 2016). They were performed 1 month before (March), 1 month after (May) and again 10 months

This article is protected by copyright. All rights reserved 
after (March) the 48-h oil exposure. Each time, the two challenge tests were conducted one week apart on fish in rearing tanks to reduce handling.

\subsubsection{Hypoxia challenge test}

The hypoxia challenge test (HCT) consisted of an initial, rapid decrease in water oxygenation (from near $100 \%$ to $20 \%$ air saturation, over $1 \mathrm{~h}$ ), followed by a slower decrease $(2 \%$ air saturation/h). Hypoxia was achieved by bubbling nitrogen through a submersible pump placed in the rearing tank. Water oxygenation was continuously monitored using an oxymeter (Ponsel Mesure). When a fish lost its ability to maintain balance, it was quickly removed from the rearing tank, identified (RFID tag reading) and placed in a fully aerated tank to recover. The corresponding time and oxygen level were also recorded. All fish recovered.

\subsubsection{Temperature challenge test}

The temperature challenge test (TCT) consisted of an initial, rapid increase in water temperature, from acclimation temperature to $27^{\circ} \mathrm{C}$, over $2.5 \mathrm{~h}$, followed by a slower increase $\left(0.5^{\circ} \mathrm{C} / \mathrm{h}\right)$ until all the fish lost equilibrium (Claireaux et al., 2013). Water temperature was controlled using two $2500 \mathrm{~W}$ heaters (GERVEN). Fish acclimation temperature was $10{ }^{\circ} \mathrm{C}$ in March and $15{ }^{\circ} \mathrm{C}$ in May.. A submersible pump placed in the tank ensured homogeneity of water temperature and air saturation (controlled by bubbling of a mixture of oxygen and air in the tank). When a fish lost its ability to maintain balance, it was quickly removed from the rearing tank, identified (RFID tag reading) and placed in a fully aerated tank at acclimation temperature to recover. The corresponding time and temperature were also recorded. All fish recovered.

This article is protected by copyright. All rights reserved 


\subsection{Chemical analyses}

To assess the severity of fish exposure and document the detoxification process, liver concentrations of 20 polycyclic aromatic hydrocarbons (including the $16 \mathrm{PAH}$ used by USEPA in fish contamination studies) were assessed $24 \mathrm{~h}$ and 1 month post exposure by GC-MS using a procedure fully described in (Lacroix et al., 2014). Briefly, PAH were extracted from liver samples using an alkaline digestion combined with stir bar sorptive extraction-thermal desorption-gas chromatography mass spectrometry (SBSE-GC-MS). Limits of detection and quantification of this analysis are summarized in Supplemental Data, Table S2.

The presence of PAH metabolites in bile was measured $24 \mathrm{~h}$ post-exposure. The concentration of bile PAH metabolites was determined semi-quantitatively using fluorescence response (Aas et al., 2000). It consisted of measuring the fluorescence with a spectrophotometer with a $5 \mathrm{~nm}$ slit width on emission and excitation channels (Jasco FP-6200, Tokyo, Japan). Analyses were performed using three excitation-emission wavelengths i.e., 295-335 (naphthalene-type metabolites); 343-383 nm (four-ringed compounds including pyrene-type metabolites) and 380-430 nm (benzo[a]pyrene-type metabolites) (Krahn et al., 1987; Lin et al., 1996; Aas et al., 2000).

\subsection{Mesocosm experiment}

On May $26^{\text {th }} 2014,400$ fish (100 per treatment group) were transported to the "National Center for Scientific Research (CNRS)" field station in L'Houmeau (450 km from Brest). The field mesocosms at L'Houmeau have been described previously (Nelson and Claireaux, 2005; Claireaux et al., 2007; Handelsman et al., 2010). Briefly, 200-m², 1-m deep earthen ponds (see picture in supplemental information S1) are connected to the nearby ocean via a canal, which This article is protected by copyright. All rights reserved 
allows partial seawater renewal with each incoming tide. Standpipes prevent fish from escaping from the ponds and bird nets prevent avian predation. In these mesocosms, fish must forage for food. Previous experiments and empirical observations have shown that the natural food web that develops in each pond can sustain a 2-3 kg fish. A complete description of the fauna of these earthen ponds can be found in (de Montaudouin and Sauriau, 2000).

Upon arrival at L'Houmeau field station, the 400 fish (100 per treatment group) were immediately distributed among 4 ponds in order to generate a high level of competition for resources within the system i.e., 25 fish per treatment per pond (approximately $2.5 \mathrm{~kg}$ ). Ponds were drained monthly (July $16^{\text {th }}$, August $27^{\text {th }}$, September $24^{\text {th }}$ ) to assess survivorship and growth, with a final assessment on November $3^{\text {rd }}$ when survivors were transported back to their original rearing facility in Brest. Throughout this field period, water conditions in the 4 ponds (oxygenation, salinity and temperature) were measured hourly using 2 MPx multi-parameter probe (NKE instrumentation, MPX, France). These 2 probes were moved alternatively between the 4 mesocosms.

\subsection{Data analysis and statistics}

Responses to performance in challenge tests did not meet the condition for ANOVA. They were therefore analyzed using a Kaplan-Meier survival analysis, followed by a log-rank test. Fish survival in the ponds was analyzed using the same procedure. Relative growth rate was calculated as follows:

$$
\frac{\ln W 2-\ln W 1}{\ln (T 2-T 1)}
$$

where W2 and W1 correspond to the fish body mass at the end (T2) and the beginning (T1) of the period considered, respectively. Time is express in days. Growth rates measured in the This article is protected by copyright. All rights reserved 
mesocosms passed the test of normality and homogeneity of variance and they were analyzed using a 2-way ANOVA. PAH concentrations in fish liver and bile fluorescence in the different exposure treatments were compared using a Kruskal-Wallis Test, followed by a Mann-Whitney $\mathrm{U}$ test. Values are presented as a mean \pm SEM and statistical significance was accepted at $\mathrm{p}<$ 0.05. The extent of inter- and intra-populational variability was assessed by measuring the coefficient of variation (CV). Coefficient of variation was calculated as follows:

$$
C V=\frac{\sigma}{\mu} \times 100
$$

Where $\sigma$ corresponds to standard deviation to $\mu$ i.e., the mean time to loss of equilibrium during the test considered. All statistical analyses were performed using R (R Core Team, 2016).

\section{Results}

\subsection{Oil Exposure}

Fish were exposed for 2 days to 4 concentrations of dispersant-treated oil. No mortality occurred during the exposure. The polycyclic aromatic hydrocarbon concentration ([PAH]) measured 1 day post-exposure in the liver of sea bass exposed to $25 \mathrm{~g}$ of oil treated with $1 \mathrm{~g}$ of dispersant $(\mathrm{O} 25 \mathrm{D} 1 ; 3.7 \pm 0.4 \mu \mathrm{g} / \mathrm{g} \mathrm{dw})$ was 5 -times higher than in the control treatment $(0.79$ $\pm 0.04 \mu \mathrm{g} / \mathrm{g} \mathrm{dw}$; Fig. 2). At that time, tricyclic PAH compounds (fluorene, dibenzothiophene, and phenanthrene) represented almost $80 \%$ of total liver $[\mathrm{PAH}]$ in exposed fish (Supplemental Data, Table S3). Consistent with the 5-fold increase in oil exposure, exposure to $125 \mathrm{~g}$ of oil treated with $5 \mathrm{~g}$ of dispersant further increased liver [PAH] by 5 -fold (O125D5; $23.7 \pm 2 \mu \mathrm{g} / \mathrm{g}$ $\mathrm{dw}$ ). The O250D10 treatment (250 g of oil plus $10 \mathrm{~g}$ of dispersant) resulted in a further $70 \%$ increase of the liver $[\mathrm{PAH}](34.3 \pm 9 \mu \mathrm{g} / \mathrm{g} \mathrm{dw})$ such that it was 40-times higher than in the This article is protected by copyright. All rights reserved 
control group. By 31 days post-exposure, liver [PAH] concentrations measured in fish from all four treatment groups had returned to background level ( 0.03 to $0.46 \mu \mathrm{g} / \mathrm{g} \mathrm{dw})$.

Bile concentration in fluorescent aromatic compounds (FAC) in fish sampled 1 day postexposure was significantly influenced by chemical exposure conditions and this, at the 3 wavelengths tested ( $<<0.001$; Fig. 3). Analysis revealed that at 295-335 nm (2- and 3-ring compounds; Fig. 3A), FAC levels measured in fish from the lowest oil exposure treatment (O25D1) were significantly higher than in fish from the control treatment $(\mathrm{p}<0.001)$. Similarly, FAC levels observed in fish from the O125D5 and O250D10 treatments were significantly higher than in fish from the CONT treatment but were statistically lower than in fish from O25D1. Concerning the 343-383 nm (4-ring compounds; Fig. 3B) and 380-430 nm (5-ring compounds; Fig. 3C) wavelengths, the O25D1, O125D5 and O250D10 treatments resulted in significantly higher fluorescence levels than the control treatment $(\mathrm{p}<0.001)$. Moreover, fluorescence levels were higher in fish from O125D5 and O250D10 treatments than in fish from O25D1 treatment $(\mathrm{p}<0.001)$. No significant difference between the O125D5 and O250D10 treatments was found $(\mathrm{p}=0.999$ at $343-383 \mathrm{~nm} ; \mathrm{p}=0.174$ at $380-430 \mathrm{~nm})$.

\subsection{Functional tests performed at 1 month post-exposure}

The responses to the challenge tests conducted 1 month post-exposure are summarized in Table 2. Mean time to loss of equilibrium (TLOE) in the hypoxia challenge test (HCT) for the control fish was $7.07 \pm 0.04 \mathrm{~h}$, which corresponded to $4.82 \pm 0.04 \%$ air saturation. No significant effect of the oil + dispersant treatments was observed $(\mathrm{p}>0.999)$. Similarly, TLOE for the control fish in the temperature challenge test (TCT) was $9.27 \pm 0.09 \mathrm{~h}$, which corresponded to $31.4 \pm$ $0.1^{\circ} \mathrm{C}$. Mean time to loss of equilibrium was not significantly influenced by exposure to oil + dispersant treatments $(\mathrm{p}=0.455)$.

This article is protected by copyright. All rights reserved 


\subsection{Mesocosm experiment}

Water conditions in the different experimental ponds were similar although daily and seasonal fluctuations were observed (Fig. 4). Independent of the season, a $5^{\circ} \mathrm{C}$ difference between nighttime minimal and daytime maximal temperatures was generally observed. The highest recorded temperature was $29.8^{\circ} \mathrm{C}\left(\mathrm{July} 25^{\text {th }}\right.$ at $\left.18: 37\right)$ and the lowest was $13.8^{\circ} \mathrm{C}\left(\right.$ October $24^{\text {th }}$ at 9:55; Fig. 4A). While water oxygen level displayed no seasonal trend, broad daily variations existed, with an evening maximum ranging between 170 to $260 \%$ air saturation and an early morning minimum varying between 30 and 50\% air saturation (Fig. 4B). Water salinity also fluctuated between 29 and 39 PSU (Fig. 4C), the main source of variability being tidal cycle and amplitude.

Growth rate in control group peaked between July $16^{\text {th }}$ and August $27^{\text {th }}(0.11 \% / d$; Fig. 5A) and progressively decreased thereafter. By the end of the experiment (November $6^{\text {th }}$ ), growth was only $1 / 15^{\text {th }}$ of that observed in August $(0.008 \% / d)$. No significant difference in growth was found among the four treatment groups ( $\mathrm{p}=0.524$; data not shown).

Fish mortality occurred mainly during the first period of the field experiment ( $15 \%$ between June $26^{\text {th }}$ and July $16^{\text {th }}$ ). By the end of the field experiment, overall survivorship exceeded $70 \%$ in all treatment groups (Fig. 5B), with no significant difference among treatments $(p=0.779)$.

\subsection{Functional tests performed at 11 months post-exposure}

The responses in the final set of challenge tests are summarized in Table 3. Mean TLOE for the control fish in the HCT was $9.09 \pm 0.20 \mathrm{~h}$, which corresponded to $4.2 \pm 0.1 \%$ air saturation. No This article is protected by copyright. All rights reserved 
significant difference $(p>0.999)$ was observed with any of the dispersant-treated oil treatments. Mean TLOE for control fish in the TCT was $4.29 \pm 0.20 \mathrm{~h}$, which corresponded to $27.8 \pm 0.1$ ${ }^{\circ} \mathrm{C}$. No effect of the dispersant-treated oil treatments was noticed $(\mathrm{p}=0.455)$.

\subsection{Intra and inter-population variability in unexposed fish}

Intra-populational variability in fish response to HCT and TCT was broad. The first loss of equilibrium at $\mathrm{HCT}$ and TCT were recorded at 2 and $2.5 \mathrm{~h}$ respectively whereas the last recordings occurred at 7.5 and $9 \mathrm{~h}$. Coefficients of variation (CV) ranged from 7 to $30 \%$ depending on the test and population considered. This is similar to what observed in Mauduit et al., (2016) were the first loss of equilibrium at HCT and TCT were observed at 3 and $8 \mathrm{~h}$ respectively while the last one were observed after 6.5 and $11 \mathrm{~h}$ in the tests.

The distributions of individuals' loss of equilibrium in the hypoxia (HCT) and temperature (TCT) challenge tests were compared to those reported in a previous study (Mauduit et al., 2016) where fish of similar origin and age, and acclimated at the same temperature, were tested (Fig. 6). Inter-populational difference in response to challenge tests was also broad. Mean times to loss of equilibrium (TLOE) at HCT and TCT in the present study $(6.43 \pm 0.06 \mathrm{~h}$ and $2.98 \pm$ $0.03 \mathrm{~h}$, respectively) were indeed, significantly lower than reported in the previous study (8.15 $\pm 0.03 \mathrm{~h}$ and $3.92 \pm 0.03 \mathrm{~h}$, respectively; $\mathrm{p}<0.001)$.

\section{Discussion}

Objectives of the present study were 1) to assess the dose-response relationship between dispersant-treated oil exposure and ecological consequences for juveniles European seabass This article is protected by copyright. All rights reserved 
(Dicentrarchus labrax), 2) to document how the pattern of natural selection modulates the ecological consequences of oil-exposure related functional impairments and their interpretation 3) to provide new insights regarding inter-population variability and its consequences in environmental impact assessment. Experimental results revealed no long-term ecological consequences of the exposure to dispersant treated oil, regardless of the dose tested. Also, fish overall survival in the field was high (> 70\%) compared to previous studies and no latent effect of the exposure was observed on fish growth and survival. However, accurate monitoring of field environmental conditions revealed that temperature and oxygen conditions may not have been challenging enough to reveal functional and ecological impairments. Furthermore, comparison of the response to challenge tests of fish from the control group tested in the present study and those tested in Mauduit et al., (2016) revealed a broad inter-population variability, precluding direct comparison of biomarkers reponses between different populations as classically practiced in impact assessment studies.

\subsection{Oil exposure}

The lowest oil-dispersant mixture concentration tested in the present work (O25D1) mimics the conditions that fish are liable to encounter when an oil spill is treated with dispersant. While total petroleum hydrocarbon concentration in water ([TPH]) was unfortunately not measured in the present study, a similar treatment (25 g of crude oil and $1 \mathrm{~g}$ of dispersant (Corexit 9500)) was tested in Mauduit et al., (2016), leading to a [TPH] of $49.4 \pm 2.3 \mathrm{mg} / \mathrm{L}^{-1}$. This concentration is in line with concentrations measured following oil spills such as Tarut Bay (Saudi Arabia, 1970), Hebei Spirit (South Korea, 2007) and Deepwater Horizon (USA, 2010) (1 to $750 \mathrm{mg} / \mathrm{L}^{-1}$; Spooner, 1970; Kim et al., 2010; Sammarco et al., 2013). The other two concentrations tested in the present work (O125D5 and O250D10) corresponded to 5 and 10-times that realistic

This article is protected by copyright. All rights reserved 
concentration and they were used to assess the limit sea bass capacity to withstand, and possibly recover from, a severe exposure to chemically dispersed oil.

One day and one month post-exposure, fish from the CONT treatment displayed background liver $[\mathrm{PAH}](0.79 \pm 0.04$ and $0.03 \pm 0.04 \mu \mathrm{g} / \mathrm{g} \mathrm{dw}$, respectively). Comparison to values measured in fish from supposedly clean areas using common-across-studies PAH validated our control condition. For instance, a [PAH] of $1.09 \mu \mathrm{g} / \mathrm{g} \mathrm{dw}$ was reported in fish from Bahia Blanca Estuary in Argentina (Arias et al., 2009), a site which displays similar geographical, physical and urbanization features than in the bay of Brest where the water used in the present study was pumped from.

One day post-exposure, concentrations measured in the liver of fish exposed to the O25D1 were similar to those measured in Mauduit et al., (2016) $(3.7 \pm 0.4 \mu \mathrm{g} / \mathrm{g} \mathrm{dw}$ and $3.0 \pm 0.2 \mu \mathrm{g} / \mathrm{g} \mathrm{dw}$, respectively). Livers concentrations measured in the liver of fish exposed to O125D5 and to O250D10 were approximately $30(23.7 \pm 2.0 \mu \mathrm{g} / \mathrm{g} \mathrm{dw})$ and 45 times higher than in fish from the CONT group $(0.79 \pm 0.04 \mu \mathrm{g} / \mathrm{g} \mathrm{dw})$. It is important to point out, however, that these values may not represent peak liver PAH concentration as fish are known to rapidly metabolize and eliminate PAH (Varanasi, 1989; van der Oost et al., 1994; Law and Hellou, 1999). A close look at the concentration in $21 \mathrm{PAH}$ (Supplemental Data, Table S3) revealed that tricyclic PAH (fluorene, dibenzothiophene, phenanthrene) represented approximately $80 \%$ of the total [PAH]. Such an imbalanced PAH proportion resulted from the weathering process which enhanced the loss of low-molecular-weight PAH (Short and Heintz, 1997; Carls et al., 1999; Heintz et al., 1999). It must be noted, however, that a preferential loss of parent PAH relative to alkylated

This article is protected by copyright. All rights reserved 
PAH has been reported recently (Liu et al., 2012), suggesting that measuring alkylated PAH would have been more representative of the true contamination conditions.

Polycyclic aromatic hydrocarbons metabolites are excreted predominantly in the bile (Krahn et al., 1982; Varanasi, 1989). As expected, fluorescence intensity measured 1 day post-exposure at $290-335 \mathrm{~nm}$ (2-ring compounds) was significantly higher in fish exposed to chemically dispersed oil than in fish from the control treatment. However, fluorescence levels were higher in fish exposed to the lowest concentration of oil-dispersant mixture (O25D1) than in the other two (O125D5 and O250D10). Surprising as it may seem, this result may simply be the consequence of the weathering process which eliminated most of the 2-ring compounds, making the fluorescence measured at those wavelengths irrelevant considering the background level of 2-ring compounds. This hypothesis is supported by the low ratio of naphthalene (the sole 2-ring PAH in the US-EPA list) to total PAH $(\approx 6 \%$ of total [PAH], Supplemental Data, Table S3) also measured in the liver. This result may also be explained by a greater induction of cytochrome P450 enzymes at higher oil concentrations and a resulting faster metabolization and excretion of low molecular weight PAH at the higher test concentrations. At 343-383 nm (4-ring compounds) and 380-430 nm (5-ring compounds), fluorescence intensity was significantly higher in fish exposed to the oil + dispersant mixtures than in fish from the control treatment. Also, the level of fluorescent aromatic compounds (FAC) increased proportionally to the nominal concentration of oil in the O25D1 and O125D5 treatments. In the O250D10, however, FAC plateaued and was similar to O125D5 treatment, suggesting a hyperbolic relationship between the nominal concentration of dispersant-treated oil in the exposure tanks and fish intake of 4 and 5-ring PAH. A hyperbolic relationship may translate either a maximized excretion rate at the highest exposure concentration or a maximized rate of bioaccumulation.

This article is protected by copyright. All rights reserved 


\subsection{Functional tests performed 1 month post-exposure}

One month post-exposure, contaminated sea bass performed as well as control fish in challenge tests (hypoxia and temperature). This result is in line with Claireaux et al., (2013), who also reported no impaired hypoxia tolerance and temperature susceptibility in sea bass 1 month postexposure to Crude Arabian Light treated with Finasol (OSR-52). This is also consistent with our previous study where fish exposed to the same low dispersant-treated oil concentration displayed no impairment in temperature susceptibility, although their hypoxia tolerance was still impaired (Mauduit et al., 2016). Several studies have reported functional impairments up to 1-month post exposure to PAH such as, for instance, impaired cardiovascular capacity and reduced critical swimming speed (Alderman, 2017; Johansen and Esbaugh, 2017). The fact that, contrary to the aforementioned studies, we observed no effect of oil exposure may be explained by several reasons. First, experimental temperatures were markedly different ranging from $10^{\circ} \mathrm{C}$ in (Alderman et al., 2016) to $14.2^{\circ} \mathrm{C}$ in (Claireaux et al., 2013) to $21^{\circ} \mathrm{C}$ in Esbaugh and Johansen (2017). Fish are ectotherm and temperature therefore affect all aspects of their physiology including the rate of pollutants uptake, accumulation and metabolization. Second, the nature of the compound tested differs widely among studies. For instance, in our previous study (Mauduit et al., 2016) we used a different dispersant (Corexit 9500) than in the present one (Finasol OSR-52) which liable to modulate oil toxicity. A higher survival of sea bass juveniles has indeed been reported after exposure to Crude Arabian Light (CAL) treated with Finasol OSR-52 compared to CAL treated with Corexit 9500 (Dussauze et al., 2015). Third oil characteristics varied extensively among the different studies. For instance, while Crude Arabian Light was used in studies from Claireaux et al., (2013) and Mauduit et al., (2016), Alderman et al., (2017) tested the effect of diluted bitumen and Johansen and Esbaugh (2017) tested the effects of water accommodated fraction (WAF). Anderson et al. (1974) have indeed

This article is protected by copyright. All rights reserved 
suggested that middle distillates were more toxic than crude oils because of higher concentrations of two- and three-ring aromatics in WAF.

\subsection{Mesocosm experiment}

Water conditions in the experimental mesocosms during spring, summer and autumn were in accordance with previous observations (Claireaux et al., 2013; Mauduit et al., 2016). Water temperatures in excess of $25^{\circ} \mathrm{C}$ recorded during late-June to early-August were in excess of the optimal temperature for sea bass $\left(22-24{ }^{\circ} \mathrm{C}\right)$. Supra-optimal temperatures are associated with decreased metabolic scope (Claireaux and Lagardère, 1999), impaired cardiac performance (Farrell et al., 2007), reduced growth (Person-Le Ruyet et al., 2004) and reduced swimming performances (Claireaux et al., 2006). As shown in Fig. 5A, water temperatures above $25^{\circ} \mathrm{C}$ occurred transiently in the mesocosm, typically $3 \mathrm{~h}$ near the end of the day when water tended to be hyperoxic (170 to $200 \%$ air saturation), whereas cooler overnight temperatures were associated with mild hypoxic condition (30 to 50\% air saturation). Although not lethal, oxygen levels below $50 \%$ air saturation may still have affected sea bass capacity to thrive in the mesocosms. For instance, the maximum swimming speed of a $15^{\circ} \mathrm{C}$-acclimated, $200 \mathrm{~g}$ sea bass is approximately $80 \mathrm{~cm} / \mathrm{s}$ and this can be achieved only under normoxic conditions (Claireaux et al., 2006). As soon as ambient oxygenation departs from full aeration, sea bass maximum swimming velocity decreases, dropping to $60 \mathrm{~cm} / \mathrm{s}$ at approximately $40 \%$ saturation. Along the same line, a sea bass feeding maximally ingests approximately $3 \%$ of its body mass in one meal, and digestion will then spread over several days. During the digestive process, an increased demand for oxygen occurs which is termed the specific dynamic action (SDA). Peak oxygen demand during SDA can be attained only at an ambient oxygen saturation $>50 \%$, otherwise fish will either not feed maximally or the digestive process will be prolonged (Lefrancois et al., 1998).

This article is protected by copyright. All rights reserved 
Compared with previous studies, overall survival rate at the end of the field experiment was high (> 70\%). For instance, preceding works using the same field site yielded survival rates ranging between 20 and 60\% (Claireaux et al., 2013; Mauduit et al., 2016). In the present study, the 96 fish that died in the ponds did so early in the experiment (between the $26^{\text {th }}$ of June and the $16^{\text {th }}$ of July), which suggests that a proportion of individuals were unable to acclimate to the field conditions and were rapidly removed from the experimental populations. During the period July-August, high survival rates were associated with high growth rates. From September to the end of November, on the other hand, growth rates progressively declined. Water temperature and oxygen level measured during that period cannot explain the reduction in growth during the fall, which is more likely attributable to reduced food availability. A similar decline in growth has also been reported in the same mesocosms (Handelsman et al., 2010; Claireaux et al., 2013; Mauduit et al., 2016).

Exposure to chemically treated oil did not affect fish survival and growth in the mesocosms, confirming the lack of ecologically relevant consequences of the exposure observed at the challenge tests conducted one month post-exposure.

\subsection{Functional tests performed 11 months post-exposure}

Eleven months post-exposure, performances at challenge tests were similar in control and oiltreated fish, confirming the lack of latent post-exposure impairment. A similar result was observed in our previous study (Mauduit et al., 2016) where no long-term effects upon sea bass hypoxia tolerance and temperature susceptibility were reported.

This article is protected by copyright. All rights reserved 


\subsection{Intra and inter-population variability in unexposed fish}

Intra-population variability in fish response to the pre-exposure hypoxia and temperature challenge tests was reported with $\mathrm{CV}$ ranging from $7 \%$ to $30 \%$ depending on the test considered. This variability can reduce statistical power (the probability that a statistical test will detect differences when they truly exist). Thus, intra-population variability implies to test large samples to circumvent this issue and avoid false negative.

In addition to this intra-populational variability, inter-populational variability is also liable to influence biomarkers interpretation. Fish performance in the pre-exposure hypoxia and temperature challenge tests were indeed different to those measured previously in Mauduit et al., (2016). Specifically, fish tested in the present study (born in 2013) displayed significantly lower hypoxia tolerance and higher temperature susceptibility than those tested in 2014 (born in 2012) ( $6.43 \pm 0.06 \mathrm{~h} v s 8.15 \pm 0.03 \mathrm{~h}$ and $2.98 \pm 0.03 \mathrm{~h} v s 3.92 \pm 0.03 \mathrm{~h}$, respectively). This is a surprising observation, especially given that these populations were obtained from the same fish farm and brood stock (but possibly with a different parental contribution), had the same age, experienced similar rearing conditions and were acclimatized to the same temperature when tested for hypoxia tolerance and temperature susceptibility $\left(11^{\circ} \mathrm{C}\right)$. This is an important result from the view point of oil spill environmental impact assessment (EIA) procedures. Typically, when an oil release occurs, EIA compares a population deemed contaminated with another one from a clean area assuming that the differences between the two populations are fully attributable to the contaminant present in one population's habitat. By revealing the extent of the difference in environmental tolerance in two control populations, we revealed that this basic assumption may be false. Moreover, we suggest that comparisons between populations from different areas and with different environmental histories should be conducted with great care as this is susceptible to yield false positive results. For instance, had we compared the 2013 This article is protected by copyright. All rights reserved 
and 2014 populations without using a control treatment for both years, we would have wrongly attributed the difference in environmental tolerance to oil-exposure.

\section{Conclusion}

In conclusion, our investigation did not reveal any long-term effects of chemically-treated oil upon fish hypoxia tolerance and temperature susceptibility, regardless of the dose tested. Furthermore, we observed a high inter-population variability in our integrated biomarkers response, precluding straightforward comparison of populations as classically practiced in impact assessment. We circumvented this difficulty by using true controls. By investigating the ecologically relevant consequences of dispersant-treated oil on a species of interest over almost a year, this study provides information of operational relevance and thus informs the pollution response process. To complete this study, further research should determine the time-course of fish recovery and its link with liver PAH metabolization kinetics, and investigate further interpopulation variability consequences on biomarkers' interpretation.

\section{Acknowledgement}

Authors would like to thank M. Hervy (Aquativ), for providing us with the fish, as well as M. Prineau (LIENSS, UMR 7266), O. Mouchel, P. Quazuguel, D. Mazurais, C. Huelvant, Y. Lemmonier, L. Cadiz (Ifremer), A. Leroy, P. Quéau (Cedre), N. Ouillon and H. Ollivier (UBO) for their technical assistance. This research was funded through ITOPF R\&D award 2012. It also received the financial support of Total Fluides. APF holds a Canada Research Chair.

\section{Data availability}

Please contact the corresponding author with data requests (florian.mauduit@gmail.com) This article is protected by copyright. All rights reserved 


\section{References}

1.

Aas E, Beyer J, Goksøyr A. 2000. Fixed wavelength fluorescence (FF) of bile as a monitoring tool for polyaromatic hydrocarbon exposure in fish: an evaluation of compound specificity, inner filter effect and signal interpretation. Biomarkers. 5:9-23.

Alderman SL, Lin F, Farrell AP, Kennedy CJ, Gillis TE. 2017. Effects of diluted bitumen exposure on juvenile sockeye salmon: from cells to performance. Environmental toxicology and chemistry. 36:354-360.

Arias AH, Spetter CV, Freije RH, Marcovecchio JE. 2009. Polycyclic aromatic hydrocarbons in water, mussels (Brachidontes sp., Tagelus sp.) and fish (Odontesthes sp.) from Bahía Blanca Estuary, Argentina. Estuarine, Coastal and Shelf Science. 85:67-81.

Brette F, Machado B, Cros C, Incardona JP, Scholz, N., Block BA. 2014. Crude Oil Impairs Cardiac Excitation-Contraction Coupling in Fish. Science. 343:769-772.

Calow P, Forbes VE. 1998. How do physiological responses to stress translate into ecological and evolutionary processes? Comparative Biochemistry and Physiology Part A: Molecular \& Integrative Physiology. 120:11-16.

6.

Carls MG, Rice SD, Hose JE. 1999. Sensitivity of fish embryos to weathered crude oil: Part I. Low-level exposure during incubation causes malformations, genetic damage, and mortality in larval pacific herring (Clupea pallasi). Environmental Toxicology and Chemistry. 18:481493.

Claireaux G, Lagardère J-P. 1999. Influence of temperature, oxygen and salinity on the metabolism of the European sea bass. Journal of Sea Research. 42:157-168.

Claireaux G, Couturier C, Groison A-L. 2006. Effect of temperature on maximum swimming speed and cost of transport in juvenile European sea bass (Dicentrarchus labrax). Journal of Experimental Biology. 209:3420-3428.

Claireaux G, Davoodi F. 2010. Effect of exposure to petroleum hydrocarbons upon cardiorespiratory function in the common sole (Solea solea). Aquatic Toxicology. 98:113-119.

Claireaux G, Désaunay Y, Akcha F, Aupérin B, Bocquené G, Budzinski H, Cravedi J-P, Davoodi F, Galois R, Gilliers C, Goanvec C, Guérault D, Imbert N, Mazéas O, Nonnotte G, Nonnotte L, Prunet P, Sébert P, Vettier A. 2004. Influence of oil exposure on the physiology and ecology of the common sole Solea solea: Experimental and field approaches. Aquatic Living Resources. 17:335-351.

Claireaux G, Handelsman C, Standen E, Nelson JA. 2007. Thermal and Temporal Stability of Swimming Performance in the European Sea Bass. Physiological and Biochemical Zoology. 80:186-196.

This article is protected by copyright. All rights reserved 
Claireaux G, Théron M, Prineau M, Dussauze M, Merlin F-X, Le Floch S. 2013. Effects of oil exposure and dispersant use upon environmental adaptation performance and fitness in the European sea bass, Dicentrarchus labrax. Aquatic Toxicology. 130-131:160-170.

Davoodi F, Claireaux G. 2007. Effects of exposure to petroleum hydrocarbons upon the metabolism of the common sole Solea solea. Marine Pollution Bulletin. 54:928-934.

de Montaudouin X, Sauriau P-G. 2000. Contribution to a synopsis of marine species richness in the Pertuis Charentais Sea with new insights in soft-bottom macrofauna of the MarennesOléron Bay. CBM-Cahiers de Biologie Marine. 41:181-222.

Dussauze M, Pichavant-Rafini K, Le Floch S, Lemaire P, Theron M. 2015. Acute toxicity of chemically and mechanically dispersed crude oil to juvenile sea bass (Dicentrarchus labrax): Absence of synergistic effects between oil and dispersants. Environ Toxicol Chem. 34:15431551 .

Esbaugh AJ, Mager EM, Stieglitz JD, Hoenig R, Brown TL, French BL, Linbo TL, Lay C, Forth H, Scholz NL, Incardona JP, Morris JM, Benetti DD, Grosell M. 2016. The effects of weathering and chemical dispersion on Deepwater Horizon crude oil toxicity to mahi-mahi (Coryphaena hippurus) early life stages. Science of The Total Environment. 543:644-651.

Farrell AP, Axelsson M, Altimiras J, Sandblom E, Claireaux G. 2007. Maximum cardiac performance and adrenergic sensitivity of the sea bass Dicentrarchus labrax at high temperatures. Journal of Experimental Biology. 210:1216-1224.

18.

Handelsman C, Claireaux G, Nelson JA. 2010. Swimming Ability and Ecological Performance of Cultured and Wild European Sea Bass (Dicentrarchus labrax) in Coastal Tidal Ponds. Physiological and Biochemical Zoology: Ecological and Evolutionary Approaches. 83:435-445.

Handelsman C, Claireaux G, Nelson JA. 2010. Swimming Ability and Ecological Performance of Cultured and Wild European Sea Bass (Dicentrarchus labrax) in Coastal Tidal Ponds. Physiological and Biochemical Zoology. 83:435-445.

Heintz RA, Rice SD, Wertheimer AC, Bradshaw RF, Thrower FP, Joyce JE, Short JW. 2000. Delayed effects on growth and marine survival of pink salmon Oncorhynchus gorbuscha after exposure to crude oil during embryonic development. Mar Ecol Prog Ser. 208:205-216.

Heintz RA, Short JW, Rice SD. 1999. Sensitivity of fish embryos to weathered crude oil: Part II. Increased mortality of pink salmon (Oncorhynchus gorbuscha) embryos incubating downstream from weathered Exxon Valdez crude oil. Environmental Toxicology and Chemistry. 18:494-503.

Incardona JP, Carls MG, Day HL, Sloan CA, Bolton JL, Collier TK, Scholz NL. 2008. Cardiac arrhythmia is the primary response of embryonic Pacific herring (Clupea pallasi) exposed to crude oil during weathering. Environmental Science \& Technology. 43:201-207.

This article is protected by copyright. All rights reserved 
Incardona JP, Carls MG, Teraoka H, Sloan CA, Collier TK, Scholz NL. 2005. Aryl hydrocarbon receptor-independent toxicity of weathered crude oil during fish development. Environmental health perspectives. 113:1755.

Incardona JP, Collier TK, Scholz NL. 2004. Defects in cardiac function precede morphological abnormalities in fish embryos exposed to polycyclic aromatic hydrocarbons. Toxicology and Applied Pharmacology. 196:191-205.

Incardona JP, Gardner LD, Linbo TL, Brown TL, Esbaugh AJ, Mager EM, Stieglitz JD, French BL, Labenia JS, Laetz CA, others. 2014. Deepwater Horizon crude oil impacts the developing hearts of large predatory pelagic fish. Proceedings of the National Academy of Sciences. 111:E1510-E1518.

ITOPF. 2016. The International Tanker Owners Pollution Federation Limited Oil Tanker Spill Statistics 2015. Retrieved October 16, 2016, from http://www.itopf.com/fileadmin/ data/Documents/Company_Lit/Oil_Spill_Stats_2016.pdf.

Johansen JL, Esbaugh AJ. 2017. Sustained impairment of respiratory function and swim performance following acute oil exposure in a coastal marine fish. Aquat. Toxicol. 187:82-89.

Khursigara AJ, Perrichon P, Martinez Bautista N, Burggren WW, Esbaugh AJ. 2017. Cardiac function and survival are affected by crude oil in larval red drum, Sciaenops ocellatus.

Science of The Total Environment. 579:797-804.

Kim M, Yim UH, Hong SH, Jung J-H, Choi H-W, An J, Won J, Shim WJ. 2010. Hebei Spirit oil spill monitored on site by fluorometric detection of residual oil in coastal waters off Taean, Korea. Marine Pollution Bulletin. 60:383-389.

Krahn MM, Burrows DG, MacLeod Jr WD, Malins DC. 1987. Determination of individual metabolites of aromatic compounds in hydrolyzed bile of English sole (Parophrys vetulus) from polluted sites in Puget Sound, Washington. Archives of Environmental Contamination and Toxicology. 16:511-522.

Krahn MM, Collier TK, Malins DC. 1982. Aromatic hydrocarbon metabolites in fish: authomated extraction and high-performance liquid chromatographic separation into conjugate and non-conjugate fractions. Journal of Chromatography A. 236:429-440.

Lacroix C, Le Cuff N, Receveur J, Moraga D, Auffret M, Guyomarch J. 2014. Development of an innovative and "green" stir bar sorptive extraction-thermal desorption-gas chromatography-tandem mass spectrometry method for quantification of polycyclic aromatic hydrocarbons in marine biota. Journal of Chromatography A. 1349:1-10.

Lam PK, Gray JS. 2003. The use of biomarkers in environmental monitoring programmes. Marine Pollution Bulletin. 46:182-186.

Law RJ, Hellou J. 1999. Contamination of fish and shellfish following oil spill incidents. Environmental Geosciences. 6:90-98.

This article is protected by copyright. All rights reserved 
Le Bihanic F, Clérandeau C, Le Menach K, Morin B, Budzinski H, Cousin X, Cachot J. 2014. Developmental toxicity of PAH mixtures in fish early life stages. Part II: adverse effects in Japanese medaka. Environmental Science and Pollution Research. 21:13732-13743.

Lefrancois C, Claireaux G, Lagardère J-P. 1998. Heart rate telemetry to study environmental influences on fish metabolic expenditure. 371.

Lessard RR, DeMarco G. 2000. The significance of oil spill dispersants. Spill Science \& Technology Bulletin. 6:59-68.

Lin EL, Cormier SM, Torsella JA. 1996. Fish biliary polycyclic aromatic hydrocarbon 38. metabolites estimated by fixed-wavelength fluorescence: comparison with HPLC-fluorescent detection. Ecotoxicology and environmental safety. 35:16-23.

Liu Z, Liu J, Zhu Q, Wu W. 2012. The weathering of oil after the Deepwater Horizon oil spill: insights from the chemical composition of the oil from the sea surface, salt marshes and sediments. Environmental Research Letters. 7:035302.

Mauduit F, Domenici P, Farrell AP, Lacroix C, Le Floch S, Lemaire P, Nicolas-Kopec A, Whittington M, Zambonino-Infante JL, Claireaux G. 2016. Assessing chronic fish health: An application to a case of an acute exposure to chemically treated crude oil. Aquatic Toxicology. 178:197-208.

McKenzie DJ, Piraccini G, Steffensen JF, Bolis CL, Bronzi P, Taylor EW. 1995. Effects of diet on spontaneous locomotor activity and oxygen consumption in Adriatic sturgeon (Acipenser naccarii). Fish Physiology and Biochemistry. 14:341-355.

Milinkovitch T, Ndiaye A, Sanchez W, Le Floch S, Thomas-Guyon H. 2011. Liver antioxidant and plasma immune responses in juvenile golden grey mullet (Liza aurata) exposed to dispersed crude oil. Aquatic Toxicology. 101:155-164.

Nelson JA, Claireaux G. 2005. Sprint Swimming Performance of Juvenile European Sea Bass. Transactions of the American Fisheries Society. 134:1274-1284.

Nelson-Smith A. 1968. The effects of oil pollution and emulsifier cleansing on shore life in south-west Britain. Journal of Applied Ecology.:97-107.

Person-Le Ruyet J, Mahe K, Le Bayon N, Le Delliou H. 2004. Effects of temperature on growth and metabolism in a Mediterranean population of European sea bass, Dicentrarchus labrax. Aquaculture. 237:269-280.

R Core Team. 2016. R: A language and environment for statistical computing. Vienna: $R$ 46. Foundation for Statistical Computing.

Ramachandran SD, Hodson PV, Khan CW, Lee K. 2004. Oil dispersant increases PAH uptake by fish exposed to crude oil. Ecotoxicology and Environmental Safety. 59:300-308.

This article is protected by copyright. All rights reserved 
Sammarco PW, Kolian SR, Warby RAF, Bouldin JL, Subra WA, Porter SA. 2013.

Distribution and concentrations of petroleum hydrocarbons associated with the BP/Deepwater Horizon Oil Spill, Gulf of Mexico. Marine Pollution Bulletin. 73:129-143.

49.

Short JW, Heintz RA. 1997. Identification of Exxon Valdez oil in sediments and tissues from Prince William Sound and the Northwestern Gulf of Alaska based on a PAH weathering model. Environmental science \& technology. 31:2375-2384.

Simmons DBD, Benskin JP, Cosgrove JR, Duncker BP, Ekman DR, Martyniuk CJ, Sherry JP. 2015. Omics for aquatic ecotoxicology: Control of extraneous variability to enhance the analysis of environmental effects. Environmental Toxicology and Chemistry. 34:1693-1704.

Spooner M. 1970. Oil spill in Tarut Bay, Saudi Arabia. Marine Pollution Bulletin. 1:166-167.

Stagg RM, Rusin J, McPhail ME, McIntosh AD, Moffat CF, Craft JA. 2000. Effects of polycyclic aromatic hydrocarbons on expression of CYP1A in salmon (Salmo salar) following experimental exposure and after the Braer oil spill. Environmental toxicology and chemistry. 19:2797-2805.

Stein JE, Collier TK, Reichert WL, Casillas E, Hom T, Varanasi U. 1992. Bioindicators of contaminant exposure and sublethal effects: studies with benthic fish in Puget Sound, Washington. Environmental Toxicology and Chemistry. 11:701-714.

UNCTAD. 2005. Review of Maritime Transport 2005. United Nations Publications.

UNCTAD. 2017. Review of Maritime Transport 2016. UN.

van der Oost R, van Gastel L, Worst D, Hanraads M, Satumalay K, van Schooten F-J, Heida H, Vermeulen NP. 1994. Biochemical markers in feral roach (Rutilus rutilus) in relation to the bioaccumulation of organic trace pollutants. Chemosphere. 29:801-817.

Vanderplancke G, Claireaux G, Quazuguel P, Madec L, Ferraresso S, Sévère A, ZamboninoInfante J-L, Mazurais D. 2015. Hypoxic episode during the larval period has long-term effects on European sea bass juveniles (Dicentrarchus labrax). Marine biology. 162:367-376.

Varanasi U. 1989. Metabolism of Polycyclic Aromatic Hydrocarbons in the Aquatic Environment. CRC Press.

Yuen B, Wong C, Woo N, Au D. 2007. Induction and recovery of morphofunctional changes in the intestine of juvenile carnivorous fish (Epinephelus coioides) upon exposure to foodborne benzo[a]pyrene. Aquatic Toxicology. 82:181-194.

This article is protected by copyright. All rights reserved 


\section{Legends}

Figure 1: Study timeline.

Figure 2: Sum of the 20 polycyclic aromatic hydrocarbons (including the 16 US-EPA listed) concentrations measured in fish liver 1 day and 1 month post-exposure. Black: control fish (CONT); blue: fish exposed to a mixture of $25 \mathrm{~g}$ of oil $+1 \mathrm{~g}$ of dispersant (O25D1); green: 125 $\mathrm{g}$ of oil $+5 \mathrm{~g}$ of dispersant (O125 + D5); red: $250 \mathrm{~g}$ of oil $+10 \mathrm{~g}$ of dispersant (O250D10). Different letters in superscript indicate statistically significant difference $(\mathrm{p}<0.05)$ and error bars correspond to the standard error to the mean (SEM).

Figure 3: Fluorescent aromatic compounds (FAC) measured 1 day post-exposure in fish bile at three wavelengths (top panel: 290-335nm; middle panel: 343-383 nm; bottom panel 380-430 $\mathrm{nm}$ ) in control fish (CONT), fish exposed to a mixture of $25 \mathrm{~g}$ of oil $+1 \mathrm{~g}$ of dispersant (O25D1), $125 \mathrm{~g}$ of oil $+5 \mathrm{~g}$ of dispersant $(\mathrm{O} 125+\mathrm{D} 5), 250 \mathrm{~g}$ of oil $+10 \mathrm{~g}$ of dispersant (O250D10). Different letters in superscript indicate statistically significant difference $(\mathrm{p}<0.05)$ and error bars correspond to the standard error to the mean (SEM).

Figure 4: Temperature (A), water oxygenation (B) and salinity (C) monitored hourly in the different ponds throughout the different ponds. Ponds are identified by different colors. Breaks in the time-series correspond to water renew and monthly drainage to recover fish.

Figure 5: Growth (A) and survival (B) monitoring over the field experiment. Black bars / line: CONT; blue bars / line: O25D1; green bars / line: O125D5; red bars / line: O250D10.

Figure 6: Kaplan-Meier analysis of time to loss of equilibrium during hypoxia (A) and temperature (B) challenge test \#1. Solid line: performances reported in Mauduit et al., 2016; dashed line: performances of fish tested in the present study.

This article is protected by copyright. All rights reserved 
Table 1: Mean time to loss of equilibrium (h) during hypoxia challenge test and temperature challenge test \#1 realized 1-month pre-exposure for fish from the different exposure subtreatments.

Table 2: Mean time to loss of equilibrium (h) during hypoxia challenge test and temperature challenge test \#2 realized 1-month post-exposure for fish from the different exposure subtreatments.

Table 3: Mean time to loss of equilibrium (h) during hypoxia challenge test and temperature challenge test \#3 realized 11 months post-exposure for fish from the different exposure subgroups.

Table 4: Sum of the concentrations in 21 polycyclic aromatic hydrocarbons measured in liver of fish from Mauduit et al., 2016 and in 20 PAH measured in the present study. In 2016 benzo(b)fluoranthene and benzo(k)fluoranthene were reported separately while in the present study they are reported together. Data correspond to the mean of 3 samples and its corresponding standard error. Concentrations are expressed in $\mu \mathrm{g}$ of PAH measured per $\mathrm{g}$ of dry liver.

This article is protected by copyright. All rights reserved 
Figure S1: Picture of one of the mesocosms used in the filed study. Credits: O. Mouchel (Ifremer).

Table S2: GC-MS limits of quantification and of detection for individual PAH in $\mathrm{ng} / \mathrm{g}$ of wet tissue. Limit of quantification was determined using the linear calibration curve according to Shrivastava et al., (2011). Limit of detection was calculated by dividing the quantification limit by 3 .

Table S3: PAH concentration in ng/g of wet tissue measured at 1 and 31 days post-exposure in liver of fish from the different exposure treatments.

This article is protected by copyright. All rights reserved 


\section{Figures}

Figure 1:

\begin{tabular}{|c|c|c|c|c|c|c|}
\hline$\sum$ Feb. & Apr. & Jun. & Aug. & Oct. & Dec. & Feb. \\
\hline
\end{tabular}

\section{Challenge tests set \#1 \\ Exposure \}

Challenge tests set $\# 2$

Field experiment

Challenge tests set \#3-

This article is protected by copyright. All rights reserved 
Figure 2:

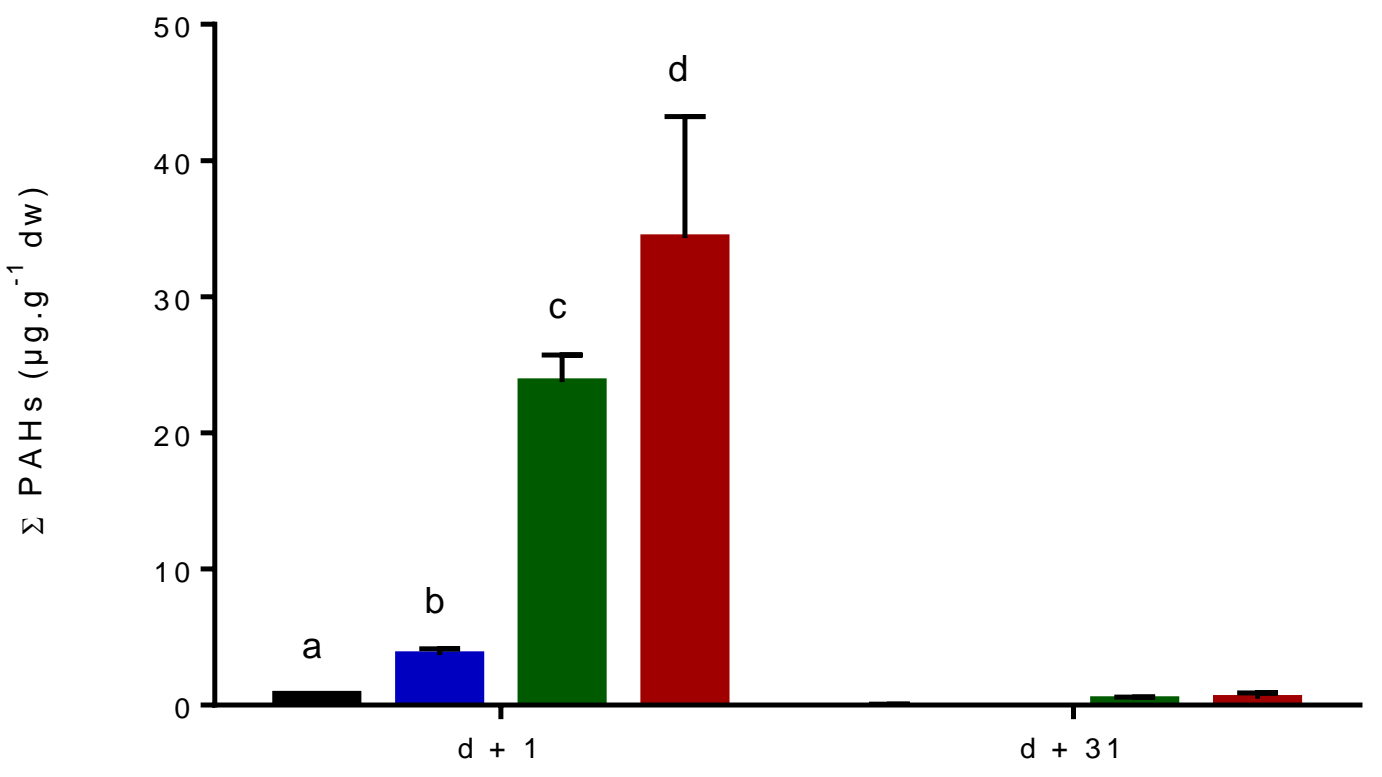

Time post-exposure

This article is protected by copyright. All rights reserved 
Figure 3:
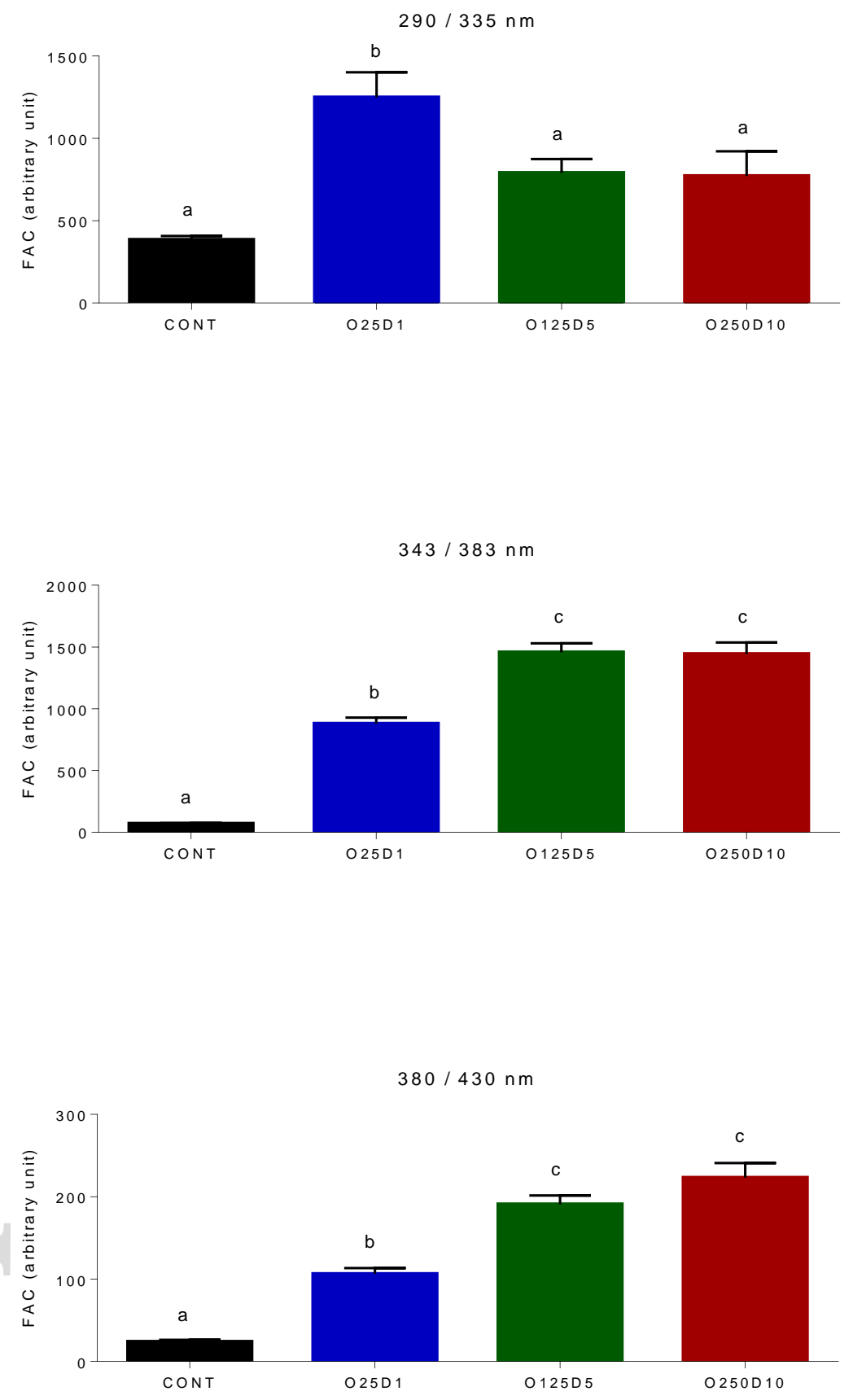

This article is protected by copyright. All rights reserved 
Figure 4:

A

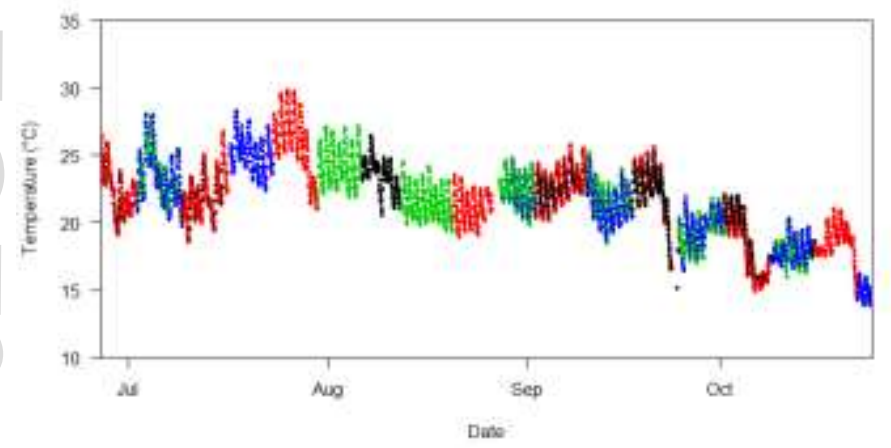

B

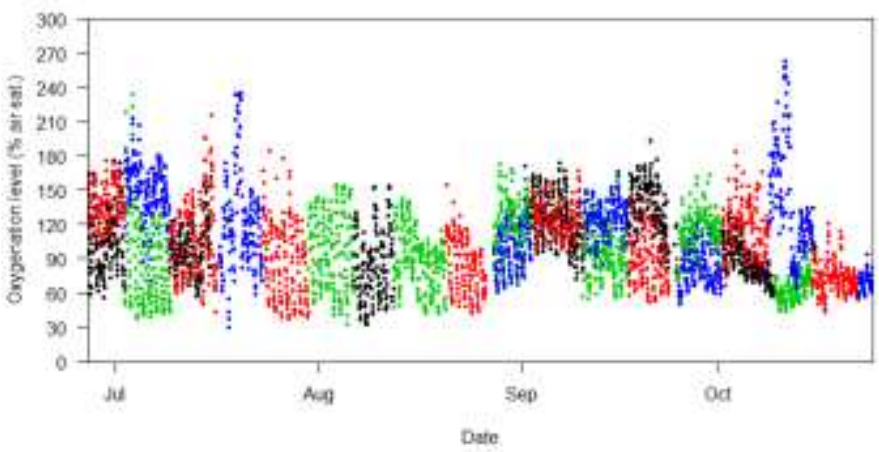

C

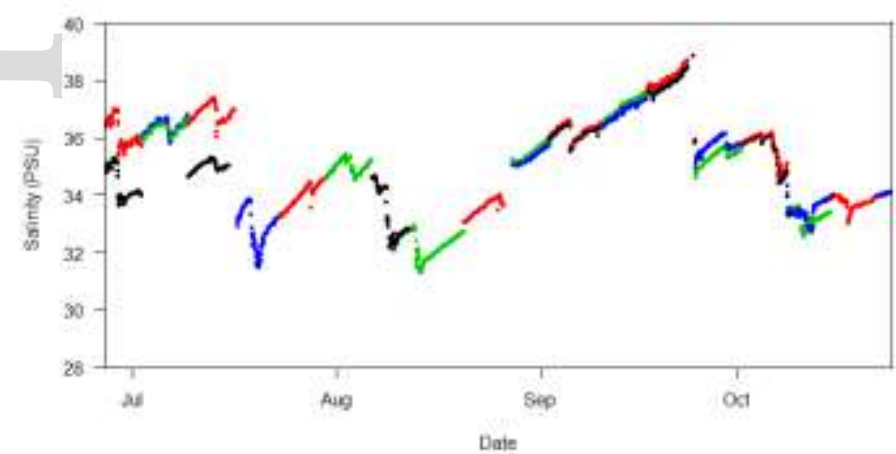

This article is protected by copyright. All rights reserved 
Figure 5:

A

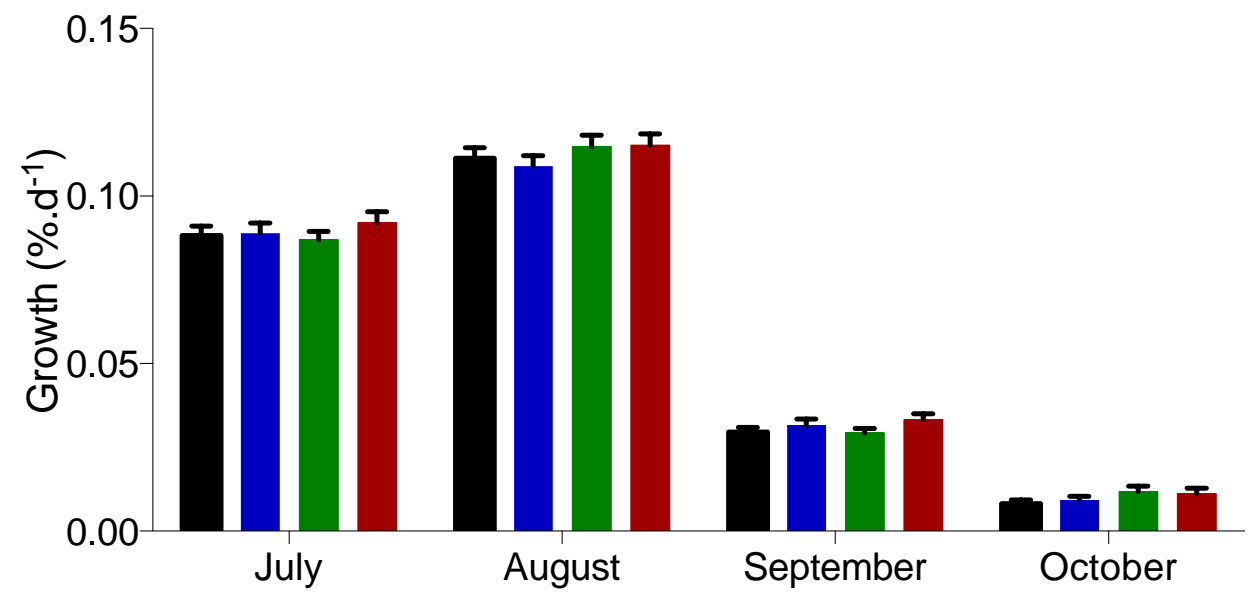

B

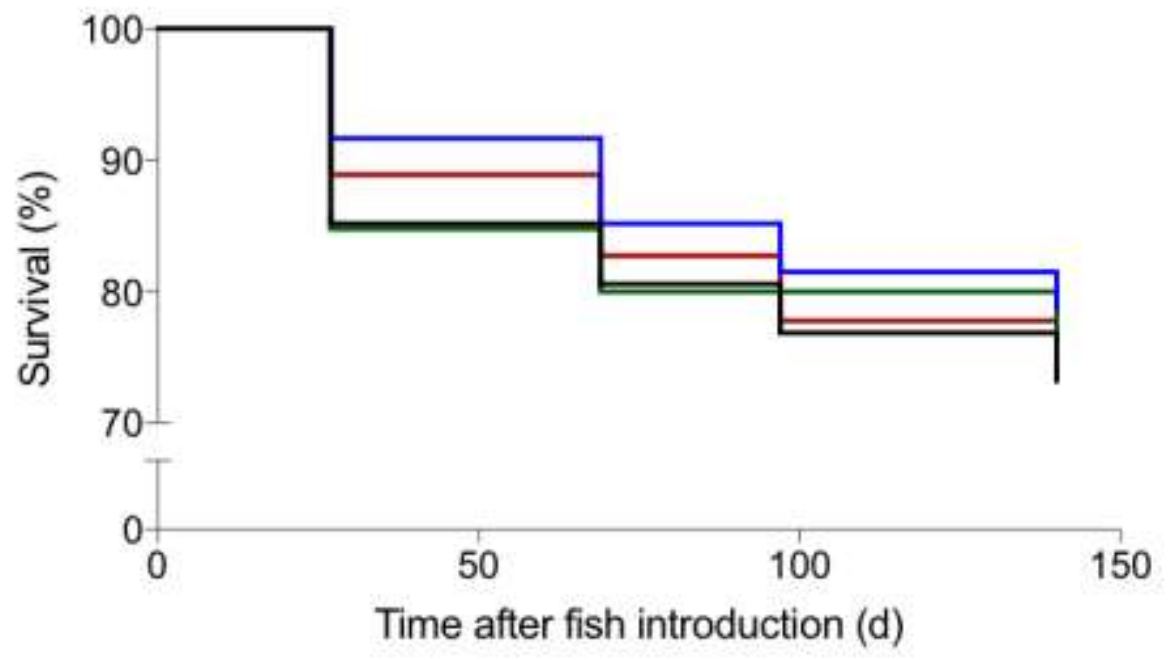

This article is protected by copyright. All rights reserved 
Figure 6:
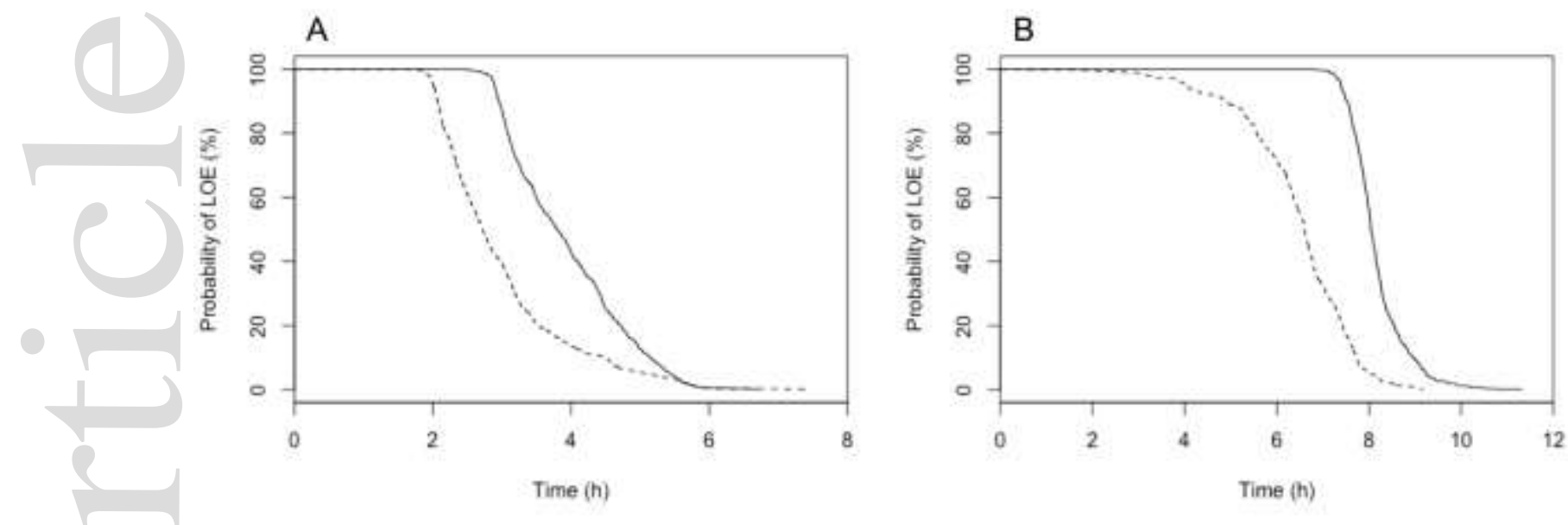

This article is protected by copyright. All rights reserved 
Table 1:

\begin{tabular}{cccccc}
\hline & \multicolumn{2}{c}{ HCT } & & \multicolumn{2}{c}{ TCT } \\
\cline { 2 - 3 } \cline { 5 - 6 } Treatment assignment & Mean TLOE & SEM & & Mean TLOE & SEM \\
\hline Control & 6.11 & 0.17 & & 2.93 & 0.09 \\
Oil 25 g + Dispersant 1 g & 6.21 & 0.17 & & 2.96 & 0.09 \\
Oil 125 g + Dispersant 5 g & 6.01 & 0.17 & & 2.88 & 0.08 \\
Oil 250 g + Dispersant 10 g & 6.56 & 0.18 & & 2.88 & 0.10 \\
\hline
\end{tabular}

HCT: hypoxia challenge test; TCT: temperature challenge test; TLOE: time to loss equilibrium

This article is protected by copyright. All rights reserved 


\section{Table 2:}

\begin{tabular}{|c|c|c|c|c|}
\hline \multirow[b]{2}{*}{ Treatment } & \multicolumn{2}{|l|}{ HCT } & \multicolumn{2}{|l|}{ TCT } \\
\hline & Mean TLOE & SEM & Mean TLOE & SEM \\
\hline Control & 7.06 & 0.04 & 9.28 & 0.09 \\
\hline Oil $25 \mathrm{~g}$ + Dispersant $1 \mathrm{~g}$ & 7.1 & 0.04 & 9.43 & 0.09 \\
\hline Oil $125 \mathrm{~g}$ + Dispersant $5 \mathrm{~g}$ & 7.06 & 0.04 & 9.45 & 0.09 \\
\hline Oil $250 \mathrm{~g}$ + Dispersant $10 \mathrm{~g}$ & 7.1 & 0.04 & 9.4 & 0.1 \\
\hline
\end{tabular}

HCT: hypoxia challenge test; TCT: temperature challenge test; TLOE: time to loss equilibrium

This article is protected by copyright. All rights reserved 


\section{Table 3:}

\begin{tabular}{|c|c|c|c|c|}
\hline \multirow[b]{2}{*}{ Treatment } & \multicolumn{2}{|l|}{ HCT } & \multicolumn{2}{|l|}{ TCT } \\
\hline & Mean TLOE & SEM & Mean TLOE & SEM \\
\hline Control & 9.1 & 0.2 & 4.3 & 0.2 \\
\hline Oil $25 \mathrm{~g}$ + Dispersant $1 \mathrm{~g}$ & 9.1 & 0.2 & 4.3 & 0.1 \\
\hline Oil $125 \mathrm{~g}$ + Dispersant $5 \mathrm{~g}$ & 8.9 & 0.2 & 3.8 & 0.1 \\
\hline Oil $250 \mathrm{~g}$ + Dispersant $10 \mathrm{~g}$ & 9.4 & 0.3 & 4.0 & 0.1 \\
\hline
\end{tabular}

HCT: hypoxia challenge test; TCT: temperature challenge test; TLOE: time to loss equilibrium

This article is protected by copyright. All rights reserved 


\section{Supplemental data}

\section{Figure S1}

\section{Table S2:}

\begin{tabular}{lcc}
\hline \multicolumn{1}{c}{ PAH } & Limit of detection $(\mathrm{ng} / \mathrm{g} \mathrm{dw})$ & Limit of quantification $(\mathrm{ng} / \mathrm{g} \mathrm{dw})$ \\
\hline Naphthalene & 6.67 & 20 \\
Benzothiophene & 6.67 & 20 \\
Biphenyl & 6.67 & 20 \\
Acenaphthylene & 6.67 & 20 \\
Acenaphthene & 6.67 & 20 \\
Fluorene & 1.33 & 4 \\
Dibenzothiophene & 0.67 & 2 \\
Phenanthrene & 1.33 & 4 \\
Anthracene & 1.33 & 4 \\
Fluoranthene & 0.67 & 2 \\
Pyrene & 1.33 & 4 \\
Benzo(a)anthracene & 1.33 & 4 \\
Chrysene & 1.33 & 4 \\
Benzo(b+k)fluoranthene & 1.33 & 4 \\
Benzo(e)pyrene & 1.33 & 4 \\
Benzo(a)pyrene & 6.67 & 20 \\
Perylene & 6.67 & 20 \\
Indeno(123-cd)pyrene & 6.67 & 20 \\
Dibenzo(ah)anthracene & 6.67 & 20 \\
Benzo(ghi)perylene & 6.67 & 20
\end{tabular}

This article is protected by copyright. All rights reserved 


\section{Table S3}

\begin{tabular}{|c|c|c|c|c|c|c|c|c|}
\hline \multirow[t]{4}{*}{$\mathrm{PAH}$} & \multicolumn{8}{|c|}{ Concentration \pm sd (ng/g dw) at 1 and 31 days post-exposure } \\
\hline & \multicolumn{4}{|c|}{$d+1$} & \multicolumn{4}{|c|}{$d+31$} \\
\hline & Control & Oil $25+$ & Oil $125+$ & Oil $250+$ & Control & Oil $25+$ & Oil $125+$ & Oil $250+$ \\
\hline & & Disp 1 & Disp 5 & Disp 10 & & Disp 1 & Disp 5 & Disp 10 \\
\hline Naphthalene & $\begin{array}{c}256 \pm \\
156\end{array}$ & $216 \pm 31$ & $2151 \pm 1313$ & $1952 \pm 1058$ & $<\mathrm{LOQ}$ & $<\mathrm{LOQ}$ & $<\mathrm{LOQ}$ & $<\mathrm{LOQ}$ \\
\hline Benzothiophene & $<\mathrm{LOQ}$ & $<\mathrm{LOQ}$ & $467 \pm 158$ & $446 \pm 102$ & $<\mathrm{LOQ}$ & $<L O Q$ & $<\mathrm{LOQ}$ & 122 \\
\hline Biphenyl & $111 \pm 6$ & $209 \pm 60$ & $1270 \pm 85$ & $2267 \pm 701$ & $<\mathrm{LOQ}$ & $<\mathrm{LOQ}$ & $<\mathrm{LOQ}$ & 74 \\
\hline Acenaphthylene & $<\mathrm{LOQ}$ & $154 \pm 35$ & $1339 \pm 90$ & $2164 \pm 728$ & $<\mathrm{LOQ}$ & $<\mathrm{LOQ}$ & $<\mathrm{LOQ}$ & 82 \\
\hline Acenaphthene & $<\mathrm{LOQ}$ & 94 & $329 \pm 14$ & $370 \pm 127$ & $<\mathrm{LOQ}$ & $<L O Q$ & $<\mathrm{LOQ}$ & $<L O Q$ \\
\hline Fluorene & $83 \pm 21$ & $320 \pm 46$ & $1724 \pm 55$ & $1327 \pm 1047$ & 21 & $<\mathrm{LOQ}$ & $54 \pm 25$ & $63 \pm 26$ \\
\hline Dibenzothiophene & $323 \pm 90$ & $2433 \pm 235$ & $13401 \pm 1769$ & $20708 \pm 6112$ & $30 \pm 26$ & $33 \pm 4$ & $314 \pm 185$ & $\begin{array}{c}294 \pm \\
206\end{array}$ \\
\hline Phenanthrene & $53 \pm 16$ & $304 \pm 28$ & $3019 \pm 496$ & $5090 \pm 2349$ & $<L O Q$ & $<\mathrm{LOQ}$ & $27 \pm$ & 26 \\
\hline Anthracene & $<\mathrm{LOQ}$ & $<\mathrm{LOQ}$ & $<\mathrm{LOQ}$ & 224 & $<\mathrm{LOQ}$ & $<L O Q$ & $<\mathrm{LOQ}$ & $<\mathrm{LOQ}$ \\
\hline Fluoranthene & $<\mathrm{LOQ}$ & $<\mathrm{LOQ}$ & $18 \pm 5$ & 9 & $<\mathrm{LOQ}$ & $<L O Q$ & $14 \pm$ & $<\mathrm{LOQ}$ \\
\hline Pyrene & $<\mathrm{LOQ}$ & $<\mathrm{LOQ}$ & $<\mathrm{LOQ}$ & 21 & $<\mathrm{LOQ}$ & $<L O Q$ & $<\mathrm{LOQ}$ & $<\mathrm{LOQ}$ \\
\hline Benzo(a)anthracene & $<\mathrm{LOQ}$ & $<\mathrm{LOQ}$ & $<\mathrm{LOQ}$ & $<\mathrm{LOQ}$ & $<\mathrm{LOQ}$ & $<L O Q$ & $<\mathrm{LOQ}$ & $<\mathrm{LOQ}$ \\
\hline Chrysene & $<\mathrm{LOQ}$ & $<\mathrm{LOQ}$ & $26 \pm 8$ & 43 & $<\mathrm{LOQ}$ & $<L O Q$ & $<\mathrm{LOQ}$ & $<\mathrm{LOQ}$ \\
\hline Benzo $(b+k)$ fluoranthene & $<\mathrm{LOQ}$ & $<\mathrm{LOQ}$ & $<\mathrm{LOQ}$ & $<\mathrm{LOQ}$ & $<\mathrm{LOQ}$ & $<L O Q$ & $<\mathrm{LOQ}$ & $<\mathrm{LOQ}$ \\
\hline Benzo(e)Pyrene & $<\mathrm{LOQ}$ & $<\mathrm{LOQ}$ & $<\mathrm{LOQ}$ & $<\mathrm{LOQ}$ & $<\mathrm{LOQ}$ & $<L O Q$ & $<\mathrm{LOQ}$ & $<\mathrm{LOQ}$ \\
\hline Benzo(a)Pyrene & $<\mathrm{LOQ}$ & $<\mathrm{LOQ}$ & $<L O Q$ & $<\mathrm{LOQ}$ & $<L O Q$ & $<L O Q$ & $<L O Q$ & $<L O Q$ \\
\hline Perylene & $<\mathrm{LOQ}$ & $<\mathrm{LOQ}$ & $<\mathrm{LOQ}$ & $<\mathrm{LOQ}$ & $<\mathrm{LOQ}$ & $<L O Q$ & $<\mathrm{LOQ}$ & $<\mathrm{LOQ}$ \\
\hline Indeno(123-cd)pyrene & $<\mathrm{LOQ}$ & $<\mathrm{LOQ}$ & $<\mathrm{LOQ}$ & $<\mathrm{LOQ}$ & $<\mathrm{LOQ}$ & $<\mathrm{LOQ}$ & $<\mathrm{LOQ}$ & $<\mathrm{LOQ}$ \\
\hline
\end{tabular}

This article is protected by copyright. All rights reserved 
Dibenzo(Ah)anthracene

Benzo(Ghi)perylene
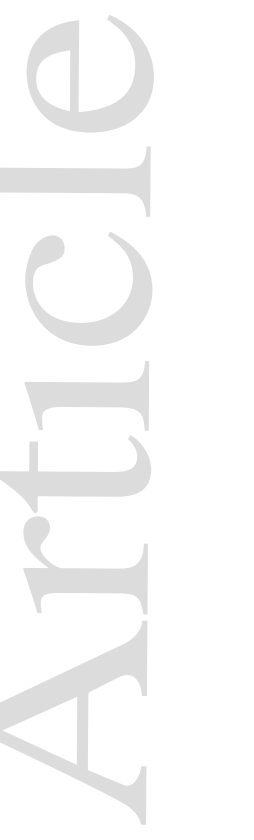

(1)

This article is protected by copyright. All rights reserved
$<$ LOQ $\quad<$ LOQ

$<$ LOQ

$<$ LOQ

$<$ LOQ

$<$ LOQ

$<$ LOQ $\quad<$ LOQ

(

$<$ LOQ
$<$ LOQ

$<$ LOQ

$<$ LOQ

$<$ LOQ

$<$ LOQ $\quad<$ LOQ $\quad<$ LOQ 